\title{
Pensions in the National Accounts: Compiling a complete picture of UK pensions including unfunded pensions for public sector employees
}

\author{
Sarah Levy, Pensions Analysis Unit, Office for National Statistics (ONS)
}

\section{Introduction}

ONS has begun work to produce, for the first time, an official estimate of the total obligations, or gross liabilities, of UK pension schemes. The work began in 2009 as part of efforts to address new international requirements for the National Accounts. These include a 'supplementary table' on pensions which all countries will have to include in their National Accounts.

A team coordinated by ONS's Pensions Analysis Unit has been set up to produce the UK supplementary table on pensions. ONS aims to produce the first set of experimental statistics for the supplementary table on pensions in December 2011, covering the year 2010. The table will include estimates of obligations for funded and unfunded pension schemes. Funded pensions are those where benefits are met from a fund built up in advance from contributions and investment income, and are found mainly in the private sector (the main exception being the Local Government Pension Scheme). Unfunded pensions are those in which obligations are not underpinned by a fund; they comprise mainly public sector employee pensions ${ }^{1}$ and state pensions. The pension payments made by the government for unfunded pensions are financed from general taxation and employee contributions.

The obligations to pay future pensions are gross liabilities from the point of view of the pension schemes. They are entitlements (or assets) from the point of view of the scheme members, so in producing estimates of total pension obligations, or gross liabilities, ONS will also be producing estimates of households' total pension entitlements, or 'pension wealth'. These entitlements include rights to state pensions as well as pensions provided through employment.

It should be noted that although we refer to pension schemes' obligations as 'liabilities', there is some debate about whether this is appropriate. On the one hand, the intention of the supplementary table is to record all pensions owing to households by private employers and the government, whether or not there are assets available to fund them; in this sense, they are liabilities. On the other hand, the amounts owing are not liabilities in the sense of debt, because it is possible to change the rules of the pension schemes and thereby change the obligations outstanding (such changes may affect service already accrued by pension scheme members as well as future service). When faced with unfunded pension obligations which are considered to be unacceptably high, it is not unusual for governments to do this.

For this reason, pension liabilities are properly defined as 'contingent pension obligations' rather than debt in the Maastrict sense. It is also important to note that 'contingent pension obligations' are not the same as 'contingent liabilities' as defined by HM Treasury for the purposes of the Whole of Government Accounts and by the Office for Budget Responsibility in its fiscal sustainability reports ${ }^{2}$. 
This article is divided into three parts. Sections 2, 3, 4 and 5 explain what the work is about, what statistics ONS intends to produce and why they will be useful. Sections 6 and 7 provide detailed information about one part of the work for which the methodology is at advanced stages of development: producing figures for unfunded pension schemes for government employees. Section 8 concludes and describes our future plans.

\section{Pensions in the National Accounts: the current position}

Information on pensions currently appears in the National Accounts in several places. For instance, contributions to pension schemes are recorded for both funded and unfunded pensions. These are attributed to the household sector, which is the beneficiary of nearly all such schemes. They also feed into the National Accounts aggregate 'compensation of employees', which is part of the income approach to measuring GDP and the calculation of the saving ratio.

Another example is that the household sector balance sheet includes an estimate of assets held in pension funds and insurance companies, and these assets are also recorded as a liability of the corporate sector (although the part relating to the Local Government Pension Scheme and other funded public sector schemes is ultimately the responsibility of Government) ${ }^{3}$.

However, there is no single place where it is possible to see both balances (stocks) and transactions (flows) for pensions. Also, the picture is incomplete from a pensions point of view. Individual personal pensions are excluded because they are not considered part of 'social insurance,4, while unfunded pensions are not included in the assets of the household sector. Even where pension assets are recorded (i.e. for funded pensions), the value shown - in the figure provided for 'life assurance and pension funds' - includes life assurance products as well as pensions, and the pensions element is not separately identifiable. Moreover, those pension liabilities which are recorded (for the corporate sector, including funded public sector schemes) are recorded on the basis that liabilities are equal to the market value of assets, rather than on an actuarial basis, which is a more appropriate way of estimating liabilities for some schemes (see Section 3).

This means that, for those interested in pensions aggregates, the National Accounts provide incomplete information. It is not possible to answer questions like 'What is the total value of pension obligations in the UK?' or 'What proportions of pension obligations belong to the private sector and to Government?' This is also the case for other countries.

However, the population of the UK, in common with the populations of other developed countries, is 'ageing" . More and more people as a proportion of the total are retired and depend - to a greater or lesser extent - on income from pensions. Although many people have other sources of income in retirement, pensions (state and private) remain the largest source of retirement income, and in the UK private pension saving is the main form of saving for retirement ${ }^{6}$. For this reason, having a complete picture of pensions aggregates is becoming increasingly important. The way that pensions are currently reported in the National Accounts is inadequate for this purpose.

\footnotetext{
3 For further information, see Pension Trends Chapter 14: Pensions in the National Accounts, available at www.statistics.gov.uk/pensiontrends
}

4 Pension schemes in social insurance comprise workplace pension schemes and state pensions accrued through National Insurance contributions. They exclude individual personal pensions, social assistance (such as Pension Credit), health or long-term care insurance and individual insurance policies. Pensions not qualifying as social insurance (individual personal pensions) are treated as a form of saving in the National Accounts.

5 See Pension Trends Chapters 2 and 3 for statistics on the ageing population and life expectancy.

6 See Pension Trends Chapters 10, 11 and 12 for statistics on saving for retirement and income sources in retirement. 
This article shows how the supplementary table on pensions will add to the information currently available in the core National Accounts, providing a complete picture of National Accounts pensions aggregates in one place. It should be noted that this article does not attempt to provide an introduction to the treatment of pensions in the core National Accounts (this is provided in Pension Trends ${ }^{7}$ ); nor does it cover how pensions transactions feature within the sequence of National Accounts, or how transactions are re-routed (this is explained in Rahman, 2007).

\section{ESA2010 and the supplementary table on pensions}

\section{ESA2010}

As required by EU regulation, the UK National Accounts are compiled according to definitions set out in the European System of Accounts (ESA), which is the EU-specific interpretation of the internationally agreed System of National Accounts (SNA). The SNA has recently been revised to produce SNA2008, and the ESA is being revised to produce ESA2010. A key change in SNA2008 and ESA2010 compared with SNA93 and ESA95 is the treatment of pensions, in particular the introduction of a 'supplementary table on pensions schemes in social insurance' (see Table 1).

\section{The supplementary table on pensions}

The supplementary table is designed to provide a complete picture of pensions, with the exception of individual personal (including stakeholder) pensions, which are excluded because they are not part of social insurance (see Section 2). It covers state pensions and all workplace private pensions, which are those shown in the first three columns of Figure 1.

In the supplementary table on pensions, pensions are defined as old age pensions and related benefits such as survivor, disability and early retirement pensions. Pensions are recorded gross (without deductions for taxes, service charges etc). The SNA2008 manual ${ }^{8}$ notes that the distinction between pension and non-pension benefits is important because "the SNA recognizes liabilities for some pensions whether there are actually assets set aside to meet the entitlements or not but recognizes reserves for non-pension benefits only when these actually exist".

The supplementary table on pensions brings together information shown in the standard or 'core' National Accounts (Columns $A$ to $F$ of the table) and information on unfunded pensions, which will not be in the core accounts but will only appear in the supplementary table (Columns $\mathrm{G}$ and $\mathrm{H}$ ). It has been argued by a number of countries, including the UK, that unfunded pension liabilities should not appear in the core accounts because they are not part of national debt.

The columns of the supplementary table also break down the information according to:

- who is the 'pension manager': private sector (Columns A-C) or Government (Columns D-H);

- the type of pension scheme: defined benefit, hybrid and defined contribution (see Box 1); and

- where the scheme appears in the National Accounts classification.

The table requires estimates of entitlements, or gross liabilities, to be calculated on an actuarial basis for defined benefit and other 'non-defined contribution' (or 'hybrid') pension schemes including those in the private sector (mainly funded, Column B), the Local Government Pension Scheme (funded, Column E), central government schemes (unfunded, Column G) and the state pension system (unfunded, Column $\mathrm{H}$ ). In the case of pure defined contribution schemes in Columns A (private sector) and D (public sector), liabilities equal assets at market value, so actuarial methods for calculating liabilities are not applicable.

7 Pension Trends Chapter 14: Pensions in the National Accounts.

8 SNA2008, paragraph 17.99. 
Table 1: Supplementary table on pension schemes in social insurance

\begin{tabular}{|c|c|c|c|c|c|c|c|c|c|c|c|c|}
\hline \multirow{5}{*}{$\begin{array}{l}\text { Rela- } \\
\text { tions }\end{array}$} & \multirow{5}{*}{$\begin{array}{l}\text { Row } \\
\text { No. }\end{array}$} & \multirow{4}{*}{$\begin{array}{r}\text { Recording } \\
\text { Pension manager } \\
\end{array}$} & \multicolumn{6}{|c|}{ Core national accounts } & \multicolumn{2}{|c|}{$\begin{array}{c}\text { Not in the core } \\
\text { national accounts }\end{array}$} & \multirow{4}{*}{$\begin{array}{l}\text { Total } \\
\text { pension } \\
\text { schemes }\end{array}$} & \multirow{4}{*}{$\begin{array}{c}\text { Counter- } \\
\text { parts: } \\
\text { Pension } \\
\text { entitle- } \\
\text { ments of } \\
\text { non- } \\
\text { resident } \\
\text { house- } \\
\text { holds }^{4)}\end{array}$} \\
\hline & & & \multicolumn{3}{|c|}{ Non-general government } & \multicolumn{5}{|c|}{ General government } & & \\
\hline & & & \multirow[b]{2}{*}{$\begin{array}{l}\text { Defined } \\
\text { con- } \\
\text { tribution } \\
\text { schemes }\end{array}$} & \multirow{2}{*}{$\begin{array}{l}\text { Defined } \\
\text { benefit } \\
\text { schemes } \\
\text { and } \\
\text { other }^{1)} \\
\text { non- } \\
\text { defined } \\
\text { contri- } \\
\text { bution } \\
\text { schemes } \\
\end{array}$} & \multirow[b]{2}{*}{ Total } & \multirow[b]{2}{*}{$\begin{array}{l}\text { Defined } \\
\text { contri- } \\
\text { bution } \\
\text { schemes }\end{array}$} & \multicolumn{3}{|c|}{$\begin{array}{c}\text { Defined benefit schemes for } \\
\text { general government employees }\end{array}$} & \multirow[b]{2}{*}{$\begin{array}{l}\text { Social } \\
\text { security } \\
\text { pension } \\
\text { schemes }\end{array}$} & & \\
\hline & & & & & & & $\begin{array}{l}\text { Classi- } \\
\text { fied in } \\
\text { financial } \\
\text { corpora- } \\
\text { tions }\end{array}$ & $\begin{array}{l}\text { Classi- } \\
\text { fied in } \\
\text { general } \\
\text { govt 3) }\end{array}$ & $\begin{array}{l}\text { Classi- } \\
\text { fied in } \\
\text { general } \\
\text { govern- } \\
\text { ment }\end{array}$ & & & \\
\hline & & Column number & A & $B$ & $\mathrm{C}$ & $\mathrm{D}$ & $\mathrm{E}$ & $F$ & G & $\mathrm{H}$ & $\mathrm{I}$ & $\mathrm{J}$ \\
\hline & & \multicolumn{11}{|c|}{ Opening balance sheet } \\
\hline & 1 & Pension entitlements & & & & & & & & & & \\
\hline & & \multicolumn{11}{|c|}{ Changes in pension entitlements due to transactions } \\
\hline $\begin{array}{l}\Sigma 2.1 \\
\text { to } 2.4\end{array}$ & 2 & $\begin{array}{l}\text { Increase in pension } \\
\text { entitlements due to } \\
\text { social contributions }\end{array}$ & & & & & & & & & & \\
\hline & 2.1 & $\begin{array}{l}\text { Employer actual } \\
\text { social contributions }\end{array}$ & & & & & & & & & & \\
\hline & 2.2 & $\begin{array}{l}\text { Employer imputed } \\
\text { social contributions }\end{array}$ & & & & & & & & & & \\
\hline & 2.3 & $\begin{array}{l}\text { Household actual } \\
\text { social contributions }\end{array}$ & & & & & & & & & & \\
\hline & 2.4 & $\begin{array}{l}\text { Household social } \\
\text { contribution } \\
\text { supplements }\end{array}$ & & & & & & & & & & \\
\hline & 3 & $\begin{array}{l}\text { Other (actuarial) } \\
\text { change of pension } \\
\text { entitlements in social } \\
\text { security pension } \\
\text { schemes }\end{array}$ & & & & & & & & & & \\
\hline & 4 & $\begin{array}{l}\text { Reduction in pension } \\
\text { entitlements due to } \\
\text { payment of pension } \\
\text { benefits }\end{array}$ & & & & & & & & & & \\
\hline \multirow[t]{7}{*}{$\begin{array}{l}2+3 \\
-4 \\
\end{array}$} & 5 & $\begin{array}{l}\text { Changes in pension } \\
\text { entitlements due to } \\
\text { social contributions } \\
\text { and pension benefits }\end{array}$ & & & & & & & & & & \\
\hline & 6 & $\begin{array}{l}\text { Transfers of pension } \\
\text { entitlements between } \\
\text { schemes }\end{array}$ & & & & & & & & & & \\
\hline & 7 & $\begin{array}{l}\text { Changes in pension } \\
\text { entitlements due to } \\
\text { pension scheme } \\
\text { reforms }\end{array}$ & & & & & & & & & & \\
\hline & & \multicolumn{11}{|c|}{ Changes in pension entitlements due to other flows } \\
\hline & 8 & $\begin{array}{l}\text { Changes in } \\
\text { entitlements due to } \\
\text { revaluations }^{6)}\end{array}$ & & & & & & & & & & \\
\hline & 9 & $\begin{array}{l}\text { Changes in } \\
\text { entitlements due to } \\
\text { other changes in } \\
\text { volume }\end{array}$ & & & & & & & & & & \\
\hline & & \multicolumn{11}{|c|}{ Closing balance sheet } \\
\hline $\begin{array}{l}1+\Sigma \\
5 \text { to } 9\end{array}$ & 10 & Pension entitlements & & & & & & & & & & \\
\hline & & \multicolumn{11}{|c|}{ Related indicators } \\
\hline & 11 & Output & & & & & & & & & & \\
\hline
\end{tabular}

1) Such other non-defined contribution schemes, often described as hybrid schemes, have both a defined benefit and a defined contribution element.

2) Schemes organised by general government for its current and former employees.

3) These are non-autonomous defined benefit schemes whose pension entitlements are recorded in the core national accounts.

4) Counterpart data for non-resident households will only be shown separately when pension relationships with the rest of the world are significant.

5) These supplements represent the return on members' claims on pension schemes, both through investment income on defined contribution schemes' assets and for defined benefit schemes through the unwinding of the discount rate applied.

6) A more detailed split of these positions should be provided for columns $\mathrm{G}$ and $\mathrm{H}$ based on the model calculations carried out for these schemes.

The cells shown as are not applicable; the cells in will contain different data from the core national accounts. 
Figure 1: Types of private pension provision in the UK

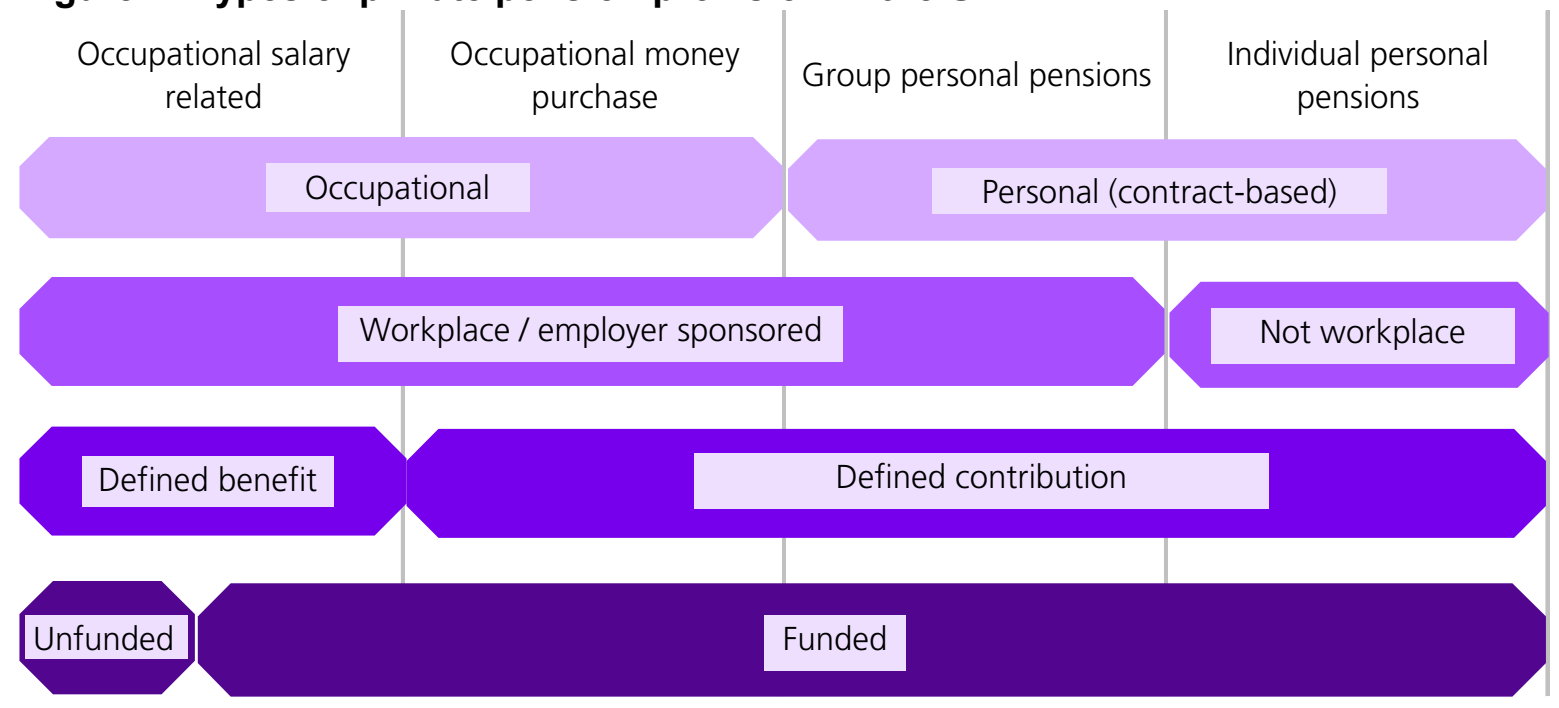

Source: Adapted from Pensions Commission (2004)

\section{Box 1: DB, DC and hybrid pension schemes}

Defined benefit (DB) schemes are those in which the rules specify the rate of benefits to be paid. The most common DB scheme is one in which the benefits are based on the number of years of pensionable service, the accrual rate and final salary. However, Career Average Revalued Earnings (CARE) schemes are becoming increasingly common in the UK. These base the pension on earnings over the whole career, adjusted by prices or earnings.

Defined contribution (DC) schemes are those in which the benefits are determined by the contributions paid into the scheme, the investment return on those contributions (less charges), and the annuity purchased on retirement. They are also known as money purchase schemes.

Hybrid schemes are those offering a choice, or mixture, of DB and DC rights at retirement. In the supplementary table on pensions, hybrid schemes are referred to as 'other non-DC schemes' and are included with DB schemes.

The rows of the supplementary table on pensions present opening and closing balances for the year (Rows 1 and 10 respectively). These are both the obligations, or gross liabilities, of pension schemes and the assets (entitlements) of the household sector. In the table, the opening and closing balances are labelled 'pension entitlements'. They are the 'present value' of gross liabilities/ entitlements accrued up to the end of the year in question.

All of the transactions which occur during the year are shown in Rows 2 to 9 of the supplementary table. Some of the transactions are actual cash flows, such as payment of actual contributions and pension benefits, while others are imputed (such as employer imputed contributions to DB pension schemes, Row 2.2) or reflect changes in actuarial assumptions used to calculate DB pension entitlements (Rows 8 and 9) or pension scheme reforms ${ }^{9}$ (Row 7 ).

9 Examples of pension scheme reforms are reforms of benefit and/or indexation rules. The impact of such reforms will only be recorded once the reforms are enacted. In cases of reforms which do not require legislation, like the replacement of the Retail Prices Index (RPI) with the Consumer Prices Index (CPI) for the indexation of public sector employee and state pensions, the impact will be recorded when the changes are announced. They will only lead to immediate changes in the figures in the supplementary table on pensions if they affect the entitlements of existing members. 


\section{European requirements and methodology}

ONS will be legally required by the EU to publish the supplementary table on pensions for every year from 2012, twelve months after the year end. ONS's intention is to publish experimental versions of the table for the years 2010 and 2011.

The ESA2010 contains a chapter on pensions (Chapter 17), which sets out how the supplementary table on pensions must be compiled. Eurostat, the EU statistical agency, and the European Central Bank (ECB) have developed additional guidelines ${ }^{10}$ with the aim of ensuring that actuarial estimates for DB schemes are compiled in a consistent manner by all EU countries, so that people can compare results across Europe on a like-for-like basis. Box 2 shows the Eurostat requirements and recommendations for assumptions used to produce actuarial estimates for governmentmanaged DB pension schemes in the supplementary table on pensions.

\section{Box 2: Assumptions for calculating actuarial estimates for government-managed schemes}

Eurostat/ECB (2011) sets out a number of requirements and recommendations on the assumptions to be used in calculating actuarial estimates for government-managed DB schemes:

\section{Requirements:}

- Real discount rate: 3 per cent (stable)

- Nominal discount rate: 5 per cent (stable), based on the real discount rate plus inflation

Recommendations:

- Inflation: 2 per cent (stable, in line with ECB medium-term inflation target)

- Uprating/indexation of pensions in payment: in accordance with country-specific indexation rules, which may be based on inflation ('price indexation'), wage growth ('wage indexation') or a mixture of the two

- Real wage growth (used to model future salary increases for members of DB schemes who have not yet reached retirement): in line with long-term productivity assumption of Ageing Working Group (AWG) for EU countries, varying between countries. AWG figures for the UK come from the Office for Budget Responsibility (the latest long-term productivity figure is 2 per cent ${ }^{11}$ )

- Nominal wage growth: real wage growth plus inflation

- Demographic assumptions (population, fertility, mortality and migration): based on Europop estimates and projections for EU countries. Figures are provided by ONS but some adjustments are made

In addition to the actuarial assumptions, in the interests of consistency and comparability across the EU, Eurostat has recommended that obligations of government-managed DB pension schemes be estimated using the projected benefit obligations (PBO) approach rather than the accumulated benefit obligations (ABO) approach. The PBO approach takes into account expected future pay increases due to career development and general wage growth, whereas the ABO approach does not. In the UK, all DB pension schemes (for employees in the private and public sectors) use the PBO method, as this is a requirement of International Accounting Standards 19 (IAS 19).

Eurostat and the ECB have also commissioned the Research Center for Generational Contracts at Freiburg University to develop a large-scale model which provides aggregate estimates of pension liabilities of DB schemes based on a comparable actuarial framework. In such actuarial models, future benefit payments to all pension scheme members are estimated each year and then these flows over time are discounted to give a single 'present value' figure for pension obligations (or gross liabilities) outstanding.

10 Eurostat/ECB (2011). See Sources and further reading.

11 This figure was published in July 2011 by the Office for Budget Responsibility (2011a). 


\section{Box 3: The discount rate}

The discount rate $(r)$ is the rate which is used to convert future payments into a 'present value' at a particular date. For example, the present value (PV) at time $(t)$ of a payment $(P)$ payable one year in future $(a t t+1)$ is calculated as:

$$
\mathrm{PV}_{t}=\frac{\mathrm{P}_{t+1}}{(1+r)}
$$

In the case of pensions, there is a stream of payments for many years into the future which are discounted to calculate the present value.

According to Eurostat/ECB (2011), the choice of discount rate is "one of the most crucial assumptions for estimating pension entitlements, since its accumulated impact over many decades can be quite high". Variations in the discount rate produce big changes in the actuarial estimate (present value) of pension entitlements, or obligations (see Section 7).

Actuaries calculating obligations of private sector pension schemes in the UK should use the yield on AA corporate bonds as the discount rate, according to IAS 19. In the past, government pension liabilities have been calculated using a different approach ${ }^{12}$, but from 2010/11 the annual 'resource accounts' for public sector unfunded pension schemes (in terms of the supplementary table on pensions, those in Column $\mathrm{G}$ ) are being prepared using a variable discount rate based on variable AA corporate bond rates and a marketbased inflation assumption, which is in line with IAS 19. The discount rate is set by HM Treasury, on advice from the Government Actuary's Department (GAD), and the same rate is used by all the public sector unfunded pension schemes which produce annual resource accounts (see Section 6).

However, the resource accounts are based on different discount rates each year because the yield on AA corporate bonds is a market rate. This makes the results difficult to interpret: short-term fluctuations caused by discount rate volatility obscure real changes caused by 'fundamentals' such as changes in longevity or assumptions about real wage growth. An alternative approach is to use a stable discount rate similar to the 'social time preference rate' used for cost benefit analysis/project appraisal by the UK Government (HM Treasury, 2003) or to the Superannuation Contribution Accruing for Past Experience (SCAPE) rate - the long-term stable discount rate used by HM Treasury to set contribution rates in public service pension scheme valuations (HM Treasury, 2010).

The pensions chapter of the ESA2010 manual ${ }^{13}$ stipulates the use of a nominal discount rate based on suitable 'risk free' rate such as the yield on high quality government or corporate bonds (AAA-rated) with 10 -year terms or more. For calculating the pension obligations of schemes for which governments are responsible, Eurostat/ECB (2011) favours a discount rate based on a basket of long-term European government bonds. It argues that "in order to guarantee comparability across countries, the same discount rate should be applied to all EU countries and for all government-managed pension schemes (including social security pension schemes) at whatever level of government" and that "a stable discount rate should be applied to avoid the noise which arises from frequent changes". It concludes that the same discount rate should be used by all 27 EU countries and that this should be a 3 per cent real (or 5 per cent nominal) discount rate.

Recent developments in the UK point in the same direction, although the rationale is different. A recent government consultation on the SCAPE rate (HM Treasury, 2010) led to a revision of this rate from 3.5 per cent (real, in excess of RPI), at which it had been fixed since the late 1990s, to 3 per cent (real, in excess of $\mathrm{CPI}$ ). The new rate, which was announced in the March 2011 budget, is based on long-term expectations for growth in the UK economy.

12 In recent years an adjustment has been made for the long-term RPI assumption. For example, at $31 \mathrm{March} 2010$, the real discount rate of $1.8 \%$ was calculated from difference between nominal AA corporate bond rates $(5.5 \%)$ and the current market expectation of future RPI inflation (3.7\%), based on the difference between the yields of indexed and nonindexed Treasury stock of the appropriate maturity. The nominal discount rate was then calculated as $1.8 \%$ (real discount rate) plus a different long-term RPI assumption (2.75\%), which equals $4.6 \%$.

13 Chapter 17, paragraph 17.167, of the 20 December 2010 draft of the ESA2010 Manual. 
Large-scale models are ideal in countries where there are few schemes and these schemes cover the whole population, so that it is possible to use whole-population economic assumptions (e.g. for wage growth) and demographic assumptions (e.g. mortality rates for men and women). It also helps if the type of pension scheme is homogeneous so that it is possible to assume that all pensions entitlements accumulate according to a simple set of rules. The standard Freiburg model is based on the rules of final salary schemes. Career average re-valued earnings (CARE) schemes and notional DC schemes are more complicated to model. CARE schemes now account for around a quarter of the membership of private sector DB pension schemes in the $\mathrm{UK}^{14}$ and may be the predominant type of scheme for public sector employees in future following the recommendations of the Independent Public Service Pensions Commission (IPSPC) chaired by Lord Hutton of Furness, which the government has announced the intention to adopt ${ }^{15}$.

In practice, because of the fact that pension systems and data sources are different in different EU countries, the goal of ensuring that actuarial estimates for DB schemes are compiled in a consistent manner by all EU countries presents some difficulties (see Section 4). However, it has been possible to agree on key points such as the use of a single, stable discount rate for government-managed pensions in all EU countries. The discount rate is a key assumption for producing actuarial estimates of pension scheme obligations (see Box 3 ).

\section{Methods and sources in the UK}

ONS has been working since October 2009 on a methodology for compiling estimates for the UK supplementary table on pensions in line with the approach required by Eurostat. There are, however, three areas where the nature of the UK pension system and the data sources available are different from the countries in continental Europe around whose systems Eurostat has built its recommended methodology:

1. Role of the state. In many continental European countries, pension systems are dominated by large pension schemes covering all employees (private and public sector) for which the government is ultimately responsible, even if employers act as facilitators. By contrast, in the UK the government is responsible for part of total pension provision - (i) the state pension and (ii) pensions for public sector employees. However, the private sector (employers and insurance companies) is also a major provider of pensions.

2. Number of schemes. Continental European countries have a small number of pension schemes covering most of the population. This means that data is relatively easy to collect and that modelling assumptions can be based on demographic data for the population as a whole. In the UK, by contrast, there are over 50,000 occupational pension schemes (most of which have fewer than 12 members), and around 3 million people are contributing to workplace pensions through individual contracts with insurance companies ${ }^{16}$. The demographic profiles cannot be assumed to be the same as those of the population as a whole. This presents a challenge for data collection and modelling.

3. Type of scheme. In countries like France and Germany, the dominant type of pension is DB - normally 'final salary' type schemes - whereas in the UK, pure DC schemes have been growing in coverage and are now equally important in terms of numbers of active members. Moreover, it is no longer possible to assume that DB schemes in the UK fit the 'final salary' model, as DB schemes in the public and private sectors are switching to the CARE model to reduce risk to providers. There are also many different types of 'hybrid' scheme, combining elements of DB and DC schemes.

14 Report of ONS's 2009 Occupational Pension Schemes Survey, Chapter 4. See Sources and further reading. 15 Independent Public Service Pensions Commission (IPSPC) (2011): Final report, see Sources and further reading.

16 The figure for occupational schemes is from the Pensions Regulator (September 2010). The estimate of people with individual contracts with insurance companies who are contributing to pensions via the workplace (mainly via group personal and stakeholder pensions) is from the 2010 Annual Survey of Hours and Earnings (see also footnote 21). 
The main implication of these differences is that in the UK, large-scale models like that developed by Freiburg University are less useful for calculating actuarial estimates of DB pension liabilities for the supplementary table. The UK pension system, with its large number of heterogeneous schemes, where the private sector is dominant and final salary schemes are in decline, requires different approaches for Columns $B, E$ and $G$. The exception is Column $H$, where such modelling is appropriate because the state pension is provided in just two 'schemes' covering most members of the UK population. The work on Column $\mathrm{H}$ is being carried out by the Department for Work and Pensions in coordination with ONS, and will be discussed in a future publication.

ONS's modified approach for Columns B, E and $G$ involves collating information from existing sources in the form of actuarial valuations and accounts. These are commissioned by scheme trustees (for private sector schemes) or by the government (for public sector schemes).

In the private sector, trustees are required to conduct actuarial valuations every three years and to calculate estimates of gross liabilities using a prudent discount rate, taking into account either or both (i) the yield on assets held by the scheme to fund future benefits and the anticipated future investment returns, and (ii) the market redemption yields on government or other high-quality bonds ${ }^{17}$. These estimates, referred to as 'technical provisions ${ }^{\prime 18}$, are the basis for returns to the Pensions Regulator which feed into our Column B estimates as well as contributing to the estimate in Column E. Separately, private sector employers (not pension schemes) are required to report gross pension liabilities in their annual accounts under IAS 19, using a discount rate in line with AA corporate bond yields.

In the public sector, actuarial valuations should be conducted every three to four years, with the purpose of estimating the present value of the pension benefits that will be paid in future, and setting contribution rates to reflect that value. These will be referred to below as 'triennial valuations'. The discount rate used is the SCAPE rate, currently set at 3 per cent real (see Box 3 ). The schemes for the civil service, NHS employees and teachers publish their valuation reports.

In addition, for the main centrally-administered public service pension schemes, annual 'resource accounts' are produced with advice from the Government Actuary's Department (GAD) or other actuaries (see Section 6). IAS 19 applies to the accounts of public sector entities, subject to adaptations and interpretations agreed by the Financial Reporting Advisory Board and set out in the Government Financial Reporting Manual (HM Treasury, 2011b).

The triennial valuations and annual accounts already contain much of the information required for the supplementary table. Where there are gaps, ONS has established that these can, in most cases, be filled by data collected by the Pensions Regulator and the Financial Services Authority and estimates from surveys and financial inquiries conducted by ONS and other government departments.

ONS believes that there is an important advantage of using actuarial valuations and annual resource accounts in the UK context, where there are many different schemes. The calculations are made by professional actuaries who take into account information specific to each scheme:

- Benefit rules: As well as the main retirement benefits, the actuaries will take account of the benefits payable in other circumstances such as early retirement due to ill health and survivors' pensions (those payable to surviving dependents if the member dies).

17 See SI 2005 No. 3377 Regulation 5(4).

18 The Pensions Act 2004 defines 'technical provisions' as the amount required to make provision for a pension scheme's liabilities, as assessed under actuarial valuation. 
- Members of the scheme: They will use detailed membership data, including information on individuals' pay and career history.

- Assumptions about the future: Assumptions such as life expectancy or the probability of early retirement due to ill health reflect the expectations for members of the specific scheme.

For pension systems like that of the UK, the results from collating information from existing sources compiled with advice from actuaries should be more accurate than those produced by centralised modelling. However, there is also a disadvantage: the sources calculate actuarial estimates of liabilities for government-managed pension schemes using different assumptions from those that Eurostat has stipulated for the supplementary table (see Box 2). The use of different assumptions can produce very different results (see below, Section 7).

ONS's view is that the use of different assumptions for wage growth, indexation of benefits and demographic factors is justifiable where the assumptions reflect the specific rules and characteristics of each pension scheme. However, for discount rates, there is no argument in favour of scheme-specific assumptions, and a consistent approach is desirable for reasons of comparability. For Columns $\mathrm{E}$ and $\mathrm{G}$ (schemes for government employees), ONS is working with GAD to convert figures in the triennial valuations and resource accounts of public service pension schemes onto the basis of a stable 5 per cent discount rate in nominal terms ( 3 per cent in real terms). This is discussed further below (Sections 6 and 7 ).

ONS hopes to be able to achieve a similar result for Column B (private sector schemes) by working with information collected by the Pensions Regulator. This stage of the work will be discussed in a later publication. However, it should be noted that if the UK follows the Eurostat guidelines for the supplementary table which require the discount rate to be the same for all schemes where the government is the pension manager ( 3 per cent real or 5 per cent nominal), while the private sector reports on the basis of market discount rates, it will not be possible to compare the results for Column $B$ with those for Columns $E$ and $G$ on a like-for-like basis ${ }^{19}$. Results are extremely sensitive to differences in the discount rate.

A final issue which particularly affects the UK relates to pure DC schemes - whether occupational schemes or workplace pension schemes based on individual contracts with insurance companies. Pure DC pensions are already a large part of UK pension provision, and this type of provision is expected to grow rapidly from 2012 with the introduction of NEST ${ }^{20}$.

UK pension provision in pure DC schemes is imperfectly measured by official statistics at present. Although we have estimates for active members of DC workplace schemes (over 4 million 'employee jobs ${ }^{\text {'21 }}$ ), there are no records of membership once people's pension funds have been converted into annuities. However, this project has established that at end-2009 insurance companies were responsible for some $£ 870$ billion of pension entitlements, of which $£ 246$ billion were in DC workplace pension pots accumulating before retirement and $£ 172$ billion was related to payment of annuities and income drawdown funds; DC pension funds managed smaller amounts.

19 It would be possible to compare the results for Column B with those for Columns $E$ and $G$ on a like-for-like basis if the results from Column $B$ could be converted onto a stable 3 per cent real (or 5 per cent nominal) discount rate basis. However, this would be extremely challenging given the number of schemes in Column $\mathrm{B}$, which will be similar to the number in the Pension Protection Fund universe reported in the 2010 Purple Book (6,850 at end-March 2010).

20 NEST (National Employment Savings Trust) is a new DC trust-based occupational pension scheme which is being introduced to meet the needs of people who are largely new to pension saving. NEST is part of the government's 2012 workplace pension reforms. For further information, see www.nestpensions.org.uk and the website of the Department for Work and Pensions (DWP): www.dwp.gov.uk/policy/pensions\%2Dreform/workplace\%2Dpension\%2Dreforms/

21 This estimate is from the Annual Survey of Hours and Earnings (ASHE) 2010. ASHE is the only survey of all workplace pensions. ASHE counts 'employee jobs' rather than individuals, but differences between the two are small. 
For pure DC pensions, it is not necessary to make actuarial estimates because liabilities are equal to assets at market value by definition. Eurostat/ECB guidelines for compiling the data for Columns $A$ and $D$ have not yet been finalised, and these columns will be discussed in a future publication.

\section{Interpreting the information - how useful will it be?}

\section{Government pension obligations}

The supplementary table on pensions will show obligations of all funded and unfunded DB pension schemes which are the responsibility of the government. This means that there will be, for the first time, a complete picture of such obligations and this picture will be updated annually. Specifically, the schemes included will be:

\section{Funded, in the core National Accounts:}

- Column E: the Local Government Pension Scheme (LGPS) and other funded schemes classified in General Government such as the BBC's DB scheme, the Transport for London scheme and schemes with a Crown guarantee such as those for members of formerly nationalised industries (railways, coal and telecommunications).

\section{Unfunded, not in the core National Accounts:}

- Column G: centrally-administered pension schemes for public sector employees, of which the main schemes are those for: civil servants, teachers, National Health Service employees, members of the Armed Forces, police officers, firefighters, the judiciary, members of the security services (MI5 and MI6), UK Atomic Energy Authority employees, DFID overseas employees and those working for the Research Councils.

- Column H: the state pension system, comprising the basic state pension and the additional state pension, which covers most people in the UK and some pensioners resident overseas.

In addition, Column D will show pure DC pension schemes which are sponsored by the UK government. However, in this case the providers are insurance companies and it is they rather than General Government who are responsible for the liabilities. An example is the civil servants' 'Partnership account', which is provided by the Standard Life, Scottish Widows and Prudential insurance companies.

At present, estimates of gross liabilities of pension schemes which are the responsibility of the UK government are not available on consistent, complete and regular bases from any official source. ONS's publication Pension Trends ${ }^{22}$ brings together what information is available, but the only figures that are regularly updated are those for Column $G$ schemes, most of which publish annual resource accounts. HM Treasury's Whole of Government Accounts (WGA), published for the first time in July 2011 (for the financial year 2009/10), are an important addition because they add the figures for public sector funded pensions to those for the Column $\mathrm{G}$ schemes.

While the resource accounts and the figures published by the WGA are useful data sources, many users may find them difficult to understand because the estimates of gross liabilities change each year reflecting short-term discount rate fluctuations. By contrast, Columns $\mathrm{E}, \mathrm{G}$ and $\mathrm{H}$ of the supplementary table on pensions will be relatively easy to interpret because they take a long-term view of pension obligations: the use of the stable discount rate (5 per cent in nominal terms, or 3 per cent in real terms) means that year-to-year changes will reflect changes in 'fundamentals'. This approach as well as other factors mean that the results presented in the supplementary table will be different from those published in the WGA reports (see Box 4).

22 Pension Trends Chapter 14: Pensions in the National Accounts. 
The complete, up-to-date picture of government-managed DB pension liabilities provided by the supplementary table on pensions will be an important addition to National Statistics. Moreover, it will be possible to compare the results with those of other EU countries which are preparing supplementary tables on pensions to similar specifications and standards.

\section{Box 4: Key differences between the supplementary table and WGA approaches}

Like ONS's supplementary table on pensions, HM Treasury's WGA publications (which are the basis for the information on pensions in OBR's fiscal sustainability reports) provide information on the government's pension obligations. However, there are some key differences between the WGA approach and that adopted by ONS for National Accounts purposes. These are:

Discount rate: OBR (2011a) notes that "we cannot easily quantify how much difference the choice of discount rate makes in aggregate, as the different accounts consolidated into the WGA use a variety of different discount rates according to their own accounting rules". This is particularly true for the LGPS, police and firefighters' pension schemes, where different discount rates are used in the accounts that are compiled annually by local authorities, which are the sources used by WGA. ONS's supplementary table overcomes this problem through a methodology based on rolling forward discount rates from the triennial valuations for these schemes and converting them onto the supplementary table basis ( 5 per cent nominal), rather than using the annual accounts compiled by local authorities (see Sections 6 and 7).

Gross vs. net liabilities: The WGA presents information for net pension liabilities. These are the same as gross pension liabilities in the case of unfunded schemes, where there are no assets. However, they are not the same in the case of funded schemes, where the net figures represent the deficit (assets minus liabilities). ONS's supplementary table on pensions shows all liabilities gross, in line with Eurostat requirements.

Scope of accounts: The two approaches are similar in terms of which public sector employee schemes are included in the accounts (see above). However, for the LGPS, police and firefighters' pension schemes the WGA approach excludes the obligations in respect of people who belong to public sector employee schemes but do/did not work for the public sector. The supplementary table on pensions shows the total obligations of all schemes. The rationale is that the pensions supplementary table aims to show the total liability that General Government is responsible for, irrespective of who is the employer. Also, the supplementary table shows all flows relating to pensions during the year, whereas in the WGA approach any payments and receipts within the public sector are consolidated out of the accounts.

State pensions: The WGA information published in July 2011 did not include estimates of obligations with respect to state pensions. ONS's supplementary table on pensions will do so.

\section{Accrued-to-date concept}

The supplementary table on pensions is prepared on an 'accrued-to-date' basis, in line with similar types of information contained in the National Accounts. The totals in Rows 1 and 10 (Columns E, $\mathrm{G}$ and $\mathrm{H}$ ) may be interpreted as the amount which the government owes in pensions for service to date. This is similar to the amount that the government would owe if the schemes were to be wound up at the date of the accounts except that this calculation may be based on the ABO method, while service to date calculations use the PBO method ${ }^{23}$.

The table will include what the WGA and OBR reports published in July 2011 refer to as future liabilities from past activities' in respect of pensions, since these are considered part of accrued-todate pension obligations. At present, 'future liabilities from past activities' are not included in the National Accounts, as liabilities are not recorded on an actuarial basis (see Section 2). When the ESA2010 changes are implemented in the core National Accounts, 'future liabilities from past

23 At the date of the accounts, PBO takes into account projected salary at retirement or earlier leaving, while ABO is based on current salary only. See above, Section 3 . 
activities' in respect of pensions will be included for those pensions which appear in the core accounts, i.e. for funded (public and private sector) pensions, but not for unfunded pensions

Liabilities of government-managed pension schemes are often thought of as part of a 'wider measure of public sector debt' which goes beyond the Maastricht definition of debt $^{24}$, although there is some debate about whether they should be included in debt measures (see Section 1). Rows 1 and 10 can also be understood as total household pension entitlements (or 'wealth') held with the government at these dates.

However, it is important to note that liabilities calculated on an 'accrued-to-date' basis are not an appropriate indicator of fiscal sustainability. This is because they only take account of the rights accumulated to date, not those which will be accumulated in the future. Fiscal sustainability is about current and future cash flows including future entitlements as they build up. Figure 2 illustrates the difference between the two concepts.

\section{Figure 2: Alternative definitions of gross liabilities}

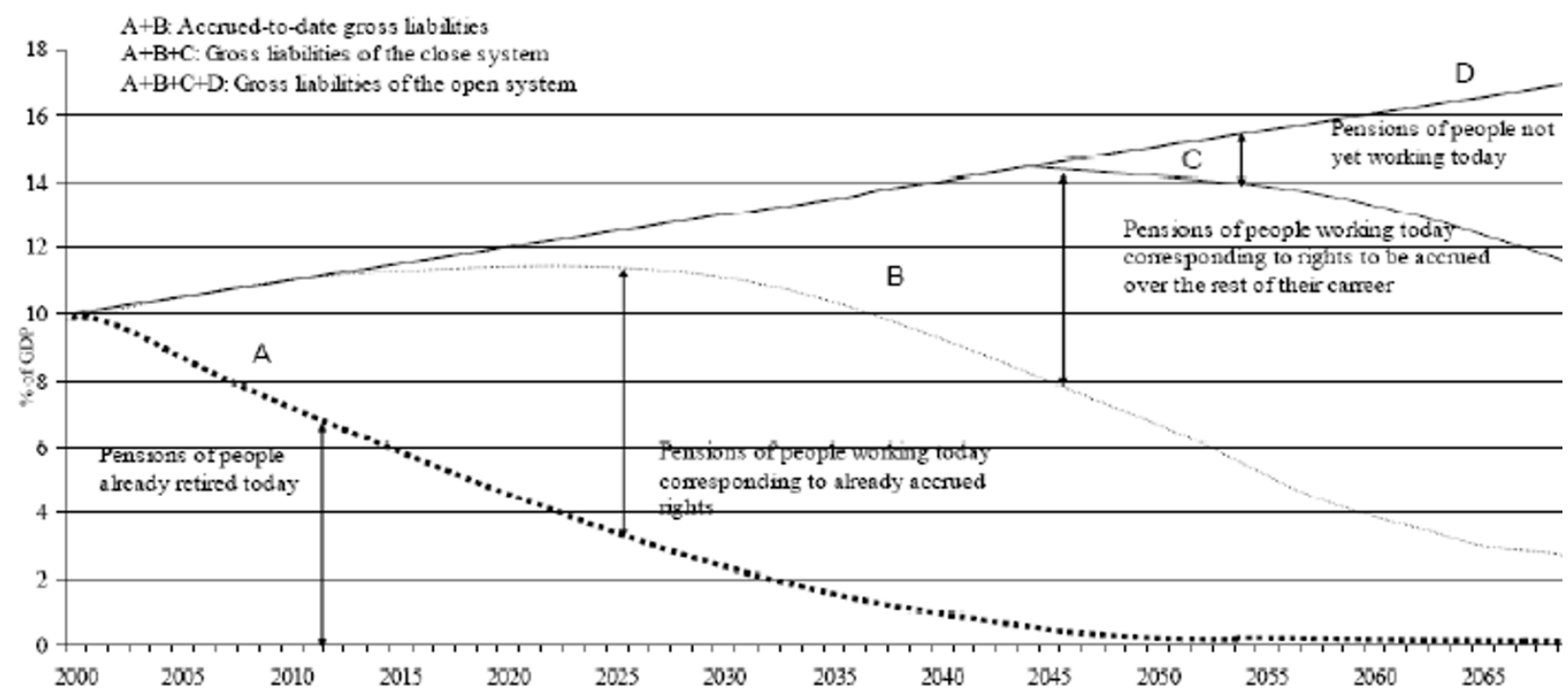

Source: European Commission Public Finance Report 2006 quoted in Eurostat/ECB (2011)

Nevertheless, it makes sense to use the same data sources and assumptions - as far as possible - for modelling fiscal sustainability ${ }^{25}$. Thus the work that ONS is doing on accrued-to-date liabilities should form an important input into work by others, such as the OBR, on fiscal sustainability of UK pensions.

\section{Private sector pension liabilities}

The supplementary table on pensions will provide an estimate of total private sector pension liabilities (gross). Although individual personal (including stakeholder) pension liabilities will not be in the supplementary table, this type of pension liability has to be estimated as part of the process of creating the table, and ONS intends to publish it in order to complete the picture.

24 Hobbs, D. (2009), Office for National Statistics: Wider measures of public sector debt: A broader approach to the public sector balance sheet. Available at www.statistics.gov.uk/articles/nojournal/wider-measures-public-sector-debt.pdf.

25 The procedure to extend the scope of accrued-to-date liabilities to a sustainability analysis is described in Müller et al (2010). 
This will be the first time that this information is published for the UK. It will also be possible to see a split between DB pension liabilities (including those of hybrid schemes) and pure DC pension liabilities. ONS expects the figures to show three things in particular:

1. The large scale of private sector pension liabilities, including those of insurance companies.

2. The relative (but declining) importance of DB versus DC pension obligations.

3. The considerable variability of private sector pension liability estimates (and therefore household pension entitlements) over time.

The UK picture is expected to be different from that of many of continental European countries. However, it will be difficult to compare the estimates for the UK private sector with those of other European countries.

- In the case of DB schemes, this is because the private sector figures in the supplementary table on pensions will be based on different discount rates, both within each EU country and between countries; these may vary both in terms of absolute level and the direction of change from year to year. For instance, the 'technical provisions' measure of total DB pension liabilities in the Pension Protection Fund (PPF) universe ${ }^{26}$ as at 31 March rose from $£ 955$ billion in 2008 to $£ 1,110$ billion in 2009 and then fell to $£ 1,074$ billion in 2010 .

- In the case of DC schemes, it is because liabilities are equal to the market value of assets, which tend to be volatile - particularly when stock markets are affected by changes in the economic cycle, as was the case during the recession of 2008-09.

This variability will also make it difficult to compare on a like-for-like basis the estimates of DB pension liabilities for the private sector (Column B) with those of government-managed schemes (Columns $\mathrm{E}$ to $\mathrm{H}$ ), where a stable discount rate applies (see Section 4). It would be possible to make like-for-like comparisons between Columns A and D, which contain DC schemes in the private and public sectors respectively. However, most government-managed schemes in the UK are DB schemes.

\section{How Column $\mathrm{G}$ is compiled}

Most of the centrally-administered unfunded pension schemes for public sector employees (Column G) have annual accounts known as 'resource accounts' which disclose information on pension entitlements/liabilities in line with International Account Standards 19 (IAS 19). The resource accounts include most of the information required for the supplementary table, although the calculations are on a different basis from that required by Eurostat for the supplementary table. Our preferred methodology where resource accounts exist is to use the information in them and make adjustments to the basis required for the supplementary table. The Government Actuary's Department (GAD) has advised ONS on how to do this.

There are two schemes in Column $\mathrm{G}$ which do not produce annual resource accounts: those for firefighters and police officers. In these cases, our preferred option is to use a method based on rolling forward some figures from the triennial valuations and combining them with data which is collected annually by government departments (see below) to produce the annual estimates that are needed for the supplementary table.

These two methods - adjusting the resource accounts and rolling forward the triennial valuations are discussed in more detail below. Further technical descriptions are available in a methodology note prepared by $G A D^{27}$. First, it is important to point out some general issues:

26 The PPF universe covers private sector DB pension schemes. Readers should note that the figures quoted here are not on a supplementary table basis, in particular because the PPF universe contains some non-private sector schemes according to the National Accounts classification system. Further work is needed to put these figures on a supplementary table basis, and will be described in future publications.

27 GAD (2011a). 
- The methodology uses existing sources and makes adjustments, in particular for the difference in discount rates between the resource accounts and the supplementary table. This provides a cost-effective solution without unacceptable compromises of accuracy (the parameter used for this purpose has been assessed, as described below). However, the results are not as accurate as performing a full actuarial valuation.

- The resource accounts of some schemes do not show separately the impact of changes in demographic assumptions (Row 9 of the supplementary table), but instead include them with changes in financial assumptions (Row 8). ONS hopes to obtain further breakdowns for the civil service pension scheme, which is the only large scheme that does not show separately the impact of changes in demographic assumptions in its resource accounts, in order to improve the results for Rows 8 and 9 and other estimates depending on them ${ }^{28}$.

- The method based on the resource accounts assumes that the main adjustment in financial assumptions in the resource accounts from year to year is of the real discount rate, not real wage growth (the other key financial assumption). It also assumes that the proportionate impact of any changes in demographic assumptions is the same when the supplementary table discount rate is used as when the resource account discount rate is used. If there are major changes in real wage growth or demographic assumptions, GAD has recommended that actuaries be consulted about the implications.

- The method based on rolling forward from the triennial valuations - the 'roll forward method' - is not capable of producing results automatically for Rows 7, 8 and 9 of the supplementary table between triennial valuations. However, figures can be estimated on a case by case basis where annual changes are known about, and then revised when information on these changes is disclosed in the next triennial valuation.

- All data sources used here are on a financial year basis (1 April to $31 \mathrm{March}$ ), so results have to be adjusted to calendar year for the supplementary table. This is a rough adjustment based on proportions.

\section{The resource accounts method}

The resource accounts are compiled every year for pension schemes of civil servants, teachers, National Health Service employees, members of the Armed Forces, the judiciary, members of the security services (MI5 and MI6), UK Atomic Energy Authority employees, DFID overseas employees and those working for the Research Councils. They conform to the requirements of IAS 19, including (from 2010/11) the use of a variable nominal discount rate based on AA corporate bond rates (see Section 3 ). Although the discount rates vary from one financial year to the next, the same discount rate is used for all the resource accounts of these schemes in a particular financial year. This is set by HM Treasury each year and announced in a Public Expenditure System (PES) note.

The resource accounts contain some information which can be used directly in the supplementary table, and some information which can be used after adjustment. Table 2 shows how the supplementary table rows are calculated using the data from the resource accounts and any adjustments, which are detailed in Appendix 1 (Table A). Table 2 also shows an example: the results for the Teachers' Pension Scheme (TPS) England and Wales.

28 Rows 8 and 9 feed into the estimates for Row 2.2, which is calculated as a balancing item from other rows; and for Rows 1 and 10 (because of the adjustment calculated using the duration parameter, which depends on Int3, see below). 
Table 2: Calculation of supplementary table Column $\mathbf{G}$ using resource accounts, on a 2009/10 financial year basis

\begin{tabular}{|c|c|c|c|c|}
\hline$\overline{\text { Row }}$ & Item & Calculation/source & $\begin{array}{l}\text { Adjustment } \\
\text { applied }\end{array}$ & $\begin{array}{l}\text { TPS England \& } \\
\text { Wales (£ million) } \\
\end{array}$ \\
\hline & Opening balance sheet & & & \\
\hline \multirow[t]{2}{*}{$\overline{1}$} & $\begin{array}{l}\text { Pension entitlements at } \\
31 \text { March } 2009\end{array}$ & $\begin{array}{l}\text { Closing balance of previous year's } \\
\text { supplementary table }\end{array}$ & & 197,331 \\
\hline & Transactions & & & \\
\hline$\overline{2}$ & Social contributions & Sum of Rows 2.1 to 2.4 & & 14,582 \\
\hline$\overline{2.1}$ & $\begin{array}{l}\text { Employer actual social } \\
\text { contributions }\end{array}$ & $\begin{array}{l}\text { Employer contributions 2009/10 from resource } \\
\text { accounts }\end{array}$ & & 3,220 \\
\hline$\overline{2.2}$ & $\begin{array}{l}\text { Employer imputed social } \\
\text { contributions }\end{array}$ & $\begin{array}{l}\text { Balancing item: Row } 10-\text { Row } 1-(\Sigma \text { Rows } 2.1 \text {, } \\
2.3,2.4,6,7,8,9)+ \text { Row } 4\end{array}$ & & -12 \\
\hline 2.3 & $\begin{array}{l}\text { Household actual social } \\
\text { contributions }\end{array}$ & $\begin{array}{l}\text { Employee contributions 2009/10 from resource } \\
\text { accounts }\end{array}$ & & 1,507 \\
\hline 2.4 & $\begin{array}{l}\text { Household social } \\
\text { contribution } \\
\text { supplements }\end{array}$ & $\begin{array}{l}\text { Row } 1 \times 5 \% \text { (nominal discount rate for } \\
\text { supplementary table) }\end{array}$ & & 9,867 \\
\hline 3 & $\begin{array}{l}\text { Other (actuarial) } \\
\text { accumulation of pension } \\
\text { entitlements in social } \\
\text { security pension funds }\end{array}$ & Not applicable & & 0 \\
\hline$\overline{4}$ & Pension benefits & $\begin{array}{l}\text { Benefits payable 2009/10 from resource } \\
\text { accounts }\end{array}$ & & 6,830 \\
\hline 5 & $\begin{array}{l}\text { Changes in pension } \\
\text { entitlements due to social } \\
\text { contributions and pension } \\
\text { benefits }\end{array}$ & Row 2 + Row 3 - Row 4 & & 7,752 \\
\hline 6 & $\begin{array}{l}\text { Transfers of entitlements } \\
\text { between schemes (net) }\end{array}$ & $\begin{array}{l}\text { Transfers in 2009/10 - Payments to and on } \\
\text { account of leavers } 2009 / 10 \text { from resource } \\
\text { accounts }\end{array}$ & & -81 \\
\hline \multirow[t]{2}{*}{$\overline{7}$} & $\begin{array}{l}\text { Changes in pension } \\
\text { entitlements due to other } \\
\text { transactions (eg arising } \\
\text { from negotiated changes } \\
\text { in scheme structure) }\end{array}$ & $\begin{array}{l}\text { Past service cost 2009/10 from resource } \\
\text { accounts (adjusted by Adj1 shown in next } \\
\text { column) }\end{array}$ & $\begin{array}{l}\text { Adj1 (adjustment of } \\
\text { entitlements from } \\
\text { the discount rate } \\
\text { used in the } \\
\text { resource accounts } \\
\text { at } 31 \text { March } 2009 \\
\text { to the stable } \\
\text { discount rate) }\end{array}$ & 22 \\
\hline & Other economic flows & & & \\
\hline$\overline{8}$ & Revaluations & $\begin{array}{l}\text { Estimated on a case by case basis where } \\
\text { necessary, otherwise nil }\end{array}$ & & 0 \\
\hline \multirow[t]{2}{*}{9} & Other changes in volume & $\begin{array}{l}\text { Changes in demographic assumptions } 2009 / 10 \\
\text { from resource accounts } \div \text { Pension entitlements } \\
\text { at } 31 \text { March } 2010 \text { from resource accounts } \times \\
\text { Row } 10\end{array}$ & & 1,941 \\
\hline & Closing balance sheet & & & \\
\hline$\overline{10}$ & $\begin{array}{l}\text { Pension entitlements at } \\
31 \text { March } 2010\end{array}$ & $\begin{array}{l}\text { Pension entitlements at } 31 \text { March } 2010 \text { from } \\
\text { resource accounts (adjusted by Adj2 shown in } \\
\text { next column) }\end{array}$ & $\begin{array}{l}\text { Adj2 (adjustment of } \\
\text { entitlements from } \\
\text { the discount rate } \\
\text { used in the } \\
\text { resource accounts } \\
\text { at } 31 \text { March } 2010 \\
\text { to the stable } \\
\text { discount rate) }\end{array}$ & 206,965 \\
\hline
\end{tabular}




\section{The roll forward method}

For the two schemes in Column $G$ which do not produce annual resource accounts, as well as for the Local Government Pension Scheme (LGPS) (Column E), our best option at present is to use a method based on 'rolling forward' figures from triennial scheme valuations to produce annual estimates. This method uses a combination of:

- information from the most recent scheme valuation (total liabilities, Standard Contribution Rate $^{29}$ and key financial assumptions i.e. nominal discount rates and/or real discount rates and/or pension increase assumption ${ }^{30}$ ); and

- information collected annually by the relevant government department ${ }^{31}$ (employer and employee contributions, benefits payable and transfers).

This method works in a similar way to the resource accounts method except for Row 2.2 of the supplementary table, which is not calculated as a balancing item; and Rows 7-9, which cannot be updated between triennial valuations except on a case by case basis (if information becomes available indicating that a change has occurred). Table 3 shows how the supplementary table rows are calculated using the roll forward method and any adjustments. The adjustments are detailed in Appendix 1 (Table B) $)^{32}$.

An alternative to the roll forward method for the police and firefighters' schemes and the LGPS would be to use information from the statutory accounts compiled each year by the employers (local authorities). This is the approach adopted by the WGA. The accounts that are compiled by local authority employers use different discount rates (see Box 4). This does not conflict with the objectives of the WGA, but it would cause problems for ONS's work on the supplementary table on pensions as it would be necessary to convert each set of accounts onto a stable discount rate basis in line with the Eurostat requirements. This would be time consuming and it would also be difficult to ensure the reliability of the resulting estimates, because it would be necessary to convert to a stable discount rate basis from many different discount rates. This is not the case with the resource accounts, which all use the same discount rate in a given financial year.

29 The Standard Contribution Rate is the total contribution rate (employer plus employee contributions) necessary to cover the cost of benefits which are being accrued by current employees, expressed as a percentage of pensionable pay. It is disclosed in actuarial valuations (GAD, 2011a).

30 It is only necessary to have two of the three key financial assumptions, as the third can be calculated from them.

31 Communities and Local Government for firefighters and the LGPS and the Home Office for the police.

32 Further information is available in GAD (2011a). 
Table 3: Calculation of supplementary table Column $\mathbf{G}$ using roll forward method, on a 2009/10 financial year basis

\begin{tabular}{llll}
\hline Row & Item & Calculation/source & Adjustment applied \\
\hline & Opening balance sheet & & \\
\hline 1 & Pension entitlements at & $\begin{array}{l}\text { Closing balance of previous year's supplementary } \\
\text { table OR total liabilities at 31 March 2009 from } \\
\text { scheme valuation (adjusted for discount rate) if } \\
\text { scheme valuation at this date exists }\end{array}$ & $\begin{array}{l}\text { Adj3 (adjustment of } \\
\text { entitlements from the discount } \\
\text { rate used in the scheme } \\
\text { valuation at 31 March 2009 to } \\
\text { the stable discount rate) }\end{array}$ \\
\end{tabular}

\begin{tabular}{|c|c|c|c|}
\hline & Transactions & & \\
\hline 2 & Social contributions & Sum of Rows 2.1 to 2.4 & \\
\hline 2.1 & $\begin{array}{l}\text { Employer actual social } \\
\text { contributions }\end{array}$ & $\begin{array}{l}\text { Employer contributions } 2009 / 10 \text { from annual data } \\
\text { collected by relevant department }\end{array}$ & \\
\hline 2.2 & $\begin{array}{l}\text { Employer imputed social } \\
\text { contributions }\end{array}$ & $\begin{array}{l}\text { Balance, after deducting Rows } 2.1 \text { and } 2.3 \text {, of } \\
\text { pensionable pay times the adjusted Standard } \\
\text { Contribution Rate. Pensionable pay is estimated as } \\
\text { employer contributions } 2009 / 10 \div \text { employer } \\
\text { contribution rate }\end{array}$ & $\begin{array}{l}\text { Adj } 4 \text { (adjustment to Standard } \\
\text { Contribution Rate during } \\
2009 / 10 \text { based on the } \\
\text { difference between the discount } \\
\text { rate used in the latest scheme } \\
\text { valuation and the stable } \\
\text { discount rate) }\end{array}$ \\
\hline 2.3 & $\begin{array}{l}\text { Household actual social } \\
\text { contributions }\end{array}$ & $\begin{array}{l}\text { Employee contributions } 2009 / 10 \text { from annual data } \\
\text { collected by relevant department }\end{array}$ & \\
\hline 2.4 & $\begin{array}{l}\text { Household social } \\
\text { contribution } \\
\text { supplements }\end{array}$ & $\begin{array}{l}\text { Row } 1 \times 5 \% \text { (nominal discount rate for supplementary } \\
\text { table) }\end{array}$ & \\
\hline 3 & $\begin{array}{l}\text { Other (actuarial) } \\
\text { accumulation of pension } \\
\text { entitlements in social } \\
\text { security pension funds }\end{array}$ & Not applicable & \\
\hline 4 & Pension benefits & $\begin{array}{l}\text { Benefits payable } 2009 / 10 \text { from annual data collected } \\
\text { by relevant department }\end{array}$ & \\
\hline 5 & $\begin{array}{l}\text { Changes in pension } \\
\text { entitlements due to social } \\
\text { contributions and pension } \\
\text { benefits }\end{array}$ & Row 2 + Row 3 - Row 4 & \\
\hline 6 & $\begin{array}{l}\text { Transfers of entitlements } \\
\text { between schemes (net) }\end{array}$ & $\begin{array}{l}\text { Transfers in } 2009 / 10 \text { - Payments to and on account of } \\
\text { leavers } 2009 / 10 \text { from annual data collected by } \\
\text { relevant department }\end{array}$ & \\
\hline \multirow[t]{2}{*}{7} & $\begin{array}{l}\text { Changes in pension } \\
\text { entitlements due to other } \\
\text { transactions (eg arising } \\
\text { from negotiated changes } \\
\text { in scheme structure) }\end{array}$ & $\begin{array}{l}\text { Estimated on a case by case basis where necessary, } \\
\text { otherwise nil }\end{array}$ & \\
\hline & Other economic flows & & \\
\hline 8 & Revaluations & $\begin{array}{l}\text { Estimated on a case by case basis where necessary, } \\
\text { otherwise nil }\end{array}$ & \\
\hline \multirow[t]{2}{*}{9} & Other changes in volume & $\begin{array}{l}\text { Estimated on a case by case basis where necessary, } \\
\text { otherwise nil }\end{array}$ & \\
\hline & Closing balance sheet & & \\
\hline 10 & $\begin{array}{l}\text { Pension entitlements at } \\
31 \text { March } 2010\end{array}$ & Row 1 plus sum of Rows $5,6,7,8$ and 9 & \\
\hline
\end{tabular}




\section{The duration parameters}

Two parameters have been developed by GAD in order to make the adjustments of the information from the scheme valuations and resource accounts onto a supplementary table basis:

- the 'duration applicable to liabilities' (Int4 in the resource account method and Data22 in the roll forward method, see Appendix 1); and

- the 'duration applicable to Standard Contribution Rate' (SCR) (Data23, see Appendix 1).

The 'duration' measures the effect on the liabilities and the SCR of changes in the discount rate; it is related to the average time until the pension benefits will be paid.

The duration applicable to liabilities $(D)$ is calculated as:

$\mathrm{D}=\frac{-\ln [\operatorname{Int} 3 / \text { Data10 }]}{\ln [(1+\operatorname{Int} 1) /(1+\operatorname{Int} 2)]}$

where:

\begin{tabular}{|l|l|}
\hline $\ln$ & natural logarithm \\
\hline Data10 & total liabilities at end of year \\
\hline Int1 & real discount rate for the start of year \\
\hline Int2 & real discount rate for the end of year \\
\hline Int3 & $\begin{array}{l}\text { liabilities at end of year using previous year's financial assumptions (Data } 10 \\
\text { minus change in financial assumptions) }\end{array}$ \\
\hline
\end{tabular}

The duration applicable to the SCR is calculated using the same formula, but Int 3 is replaced by the SCR at the end of the year using the previous year's financial assumptions and Data10 is replaced by the SCR at the end of the year.

Further information on the practical challenges of estimating these durations is provided in GAD (2011b). The GAD note also points out that adjustments using such duration parameters are only an approximate method, although they are more accurate than simple linear extrapolations. GAD recommends testing the results by using a range of durations and assessing their impact on the relevant figures.

\section{Employer imputed social contributions}

When compiling the supplementary table on pensions from the resource accounts, employer imputed social contributions (Row 2.2) are calculated as a balancing item: pension entitlements at the end of the year minus the pension entitlements at the start year and all flows during the year (see Table 2). This row is very sensitive to the estimation of pension entitlements. As Row 2.2 is a component of Rows 2 and 5, these rows are also sensitive to the estimation of the pension entitlements at the beginning and end of each year.

GAD (2011a) notes that calculating the duration applicable to the liabilities using the information drawn from the same resource accounts as the data on the level of the entitlements in the start year and end year helps to provide consistency and reduce the volatility of Row 2.2.

Row 2.2 is perhaps one of the most difficult to interpret in the supplementary table. What is meant by 'employer imputed social contributions'? ESA2010 Chapter 17 notes that:

"Any changes in entitlements over the year not included in other rows of the table are captured in row 2.2. This row covers also any 'experience effects' where the observed 
outcome of pension modelling assumptions (real wage growth rate, discount rate) differs from the levels assumed".

In the resource accounts of the unfunded public sector pension schemes, these 'experience effects' are referred to as 'experience gains and losses'. Experience gains and losses reflect differences between the assumed rate of inflation and actual inflation during the year, differences between assumed wage growth and actual increases during the year, and other factors such as where actual survival rates are lower or higher than the assumed rates.

Row 2.2 also contains the difference between, on the one hand, what the resource accounts refer to as 'current service cost', which is the increase in liabilities resulting from employee service during the year, and, on the other hand actual cash contributions received during the year. The figures for current service cost reflect the discount rate used for the supplementary table, while actual cash contributions received are based on the calculations made for the scheme valuations; if there is a difference between the two (i.e. if the discount rate used for the supplementary table on pensions and the SCAPE rate are different), this will be reflected in Row $2.2^{33}$. Also, actual cash contributions received may be adjusted upwards or downwards to reflect past events (via the contribution rate set by the latest scheme valuation).

One interpretation of Row 2.2 is that a large positive amount means that contributions received during the year are not enough to meet the change in the scheme's liabilities. It would appear logical to conclude that actual contributions - which may have been set several years previously in the last triennial valuation - need to be increased and/or that some of the assumptions need to be changed to make them more realistic. However, GAD's advice is that care should be taken before reaching this conclusion because experience effects are volatile: they may be positive one year but negative the next. An established pattern of experience effects over several years, however, would indicate that the assumptions should be reviewed ${ }^{34}$.

\section{Sensitivity analysis for Column G}

The figures for the entitlements of public sector employees in unfunded schemes that are published in the schemes' resource accounts show big year-on-year variations. Table 4 shows, for the largest four schemes - those for civil servants, teachers, National Health Service employees and members of the Armed Forces - how estimates of entitlements (the obligations or liabilities of schemes) have varied in recent years. The explanations provided in the resource accounts is that these changes are mainly due to changes in the discount rate, which varies from year to year because it is based on AA corporate bond rates (see Box 3). From time to time changes in other financial assumptions also affect estimates of obligations, as do changes in demographic assumptions.

33 If the discount rate used for the supplementary table is lower than the SCAPE rate, the measured value in the supplementary table of the increase in liabilities resulting from employee service during the year will be greater than the contributions actually paid, and this will produce a positive contribution to Row 2.2, particularly for schemes with a large proportion of active members relative to pensioner members ('young schemes').

34 Also, if the discount rate used for the supplementary table and the SCAPE rate are different, amounts shown in Row 2.2 will reflect differences between the discount rate used for the supplementary table and the SCAPE rate. 
Table 4: Liabilities of largest four unfunded public service pension schemes

\begin{tabular}{lrrrrr} 
United Kingdom & \multicolumn{3}{c}{} & & $£$ billion \\
\hline National Health Service & 2006 & 2007 & 2008 & 2009 & 2010 \\
Teachers & 189 & 249 & 242 & 227 & 329 \\
Civil Service (Great Britain) & 164 & 208 & 204 & 194 & 258 \\
Armed Forces & 101 & 129 & 119 & 116 & 153 \\
\hline Total (four largest schemes) & 76 & 101 & 97 & 91 & 121 \\
\% compared with previous year & 530 & 687 & 663 & 628 & 861 \\
Real discount rate used (\%) & 2.8 & $130 \%$ & $96 \%$ & $95 \%$ & $137 \%$ \\
\hline
\end{tabular}

Source: Schemes' annual resource accounts as at 31 March

In the case of Column G of the supplementary table on pensions, variability in estimates of scheme liabilities due to changes in the discount rate are eliminated by the use of a stable discount rate (5 per cent in nominal terms), but other assumptions may change. Table 5 shows the central assumptions used when compiling accounts for Column $G$ schemes on a supplementary table basis. An important aspect of the work on the supplementary table is to test how sensitive are the estimates of liabilities to changes in these assumptions. A methodology for doing this has been developed by GAD.

Table 5: Central assumptions used to compile accounts on supplementary table basis for Column G schemes

\begin{tabular}{|l|l|}
\hline Discount rate (nominal) & $5 \%$ \\
\hline Inflation & $2 \%$ \\
\hline $\begin{array}{l}\text { Assumed future rate of increases in } \\
\text { pensions (nominal) }\end{array}$ & $\begin{array}{l}\text { In line with pension increase policy, i.e.: } \\
-\quad \text { Before change from RPI to } \mathrm{CPI}: 2.75 \% \\
-\quad \text { Following change: } 2 \%\end{array}$ \\
\hline Wage growth (nominal) & $\begin{array}{l}\text { Stable } 4.25 \% \text { (equivalent to } 2.25 \% \text { in excess of } \\
\text { long-term inflation assumption of } 2 \% \text { ) }\end{array}$ \\
\hline Current mortality rates & $\begin{array}{l}\text { Based on recent experience of pensioners in } \\
\text { public service pension schemes - longer life } \\
\text { expectancy than general population }\end{array}$ \\
\hline Future improvements in mortality rates & $\begin{array}{l}\text { Based on future improvements in mortality rates } \\
\text { assumed in ONS national population projections }- \\
\text { currently 2008-based principal projections }\end{array}$ \\
\hline
\end{tabular}

* The change from the Retail Prices Index (RPI) to the Consumer Prices Index (CPI) for indexation of public sector employee and state pensions was announced in the June 2010 budget. The resource accounts will recognise the change as at June 2010, so it will appear in the resource accounts for 2010/11. For the sensitivity analysis in this section we have used the 'before change' (RPI) assumption of $2.75 \%$ as the central assumption for pension indexation.

The rest of this section discusses what happens to the estimate of pension liabilities when the assumptions change. Each assumption in turn is varied, while holding the other assumptions constant. Further information on the methodology used to calculate these 'sensitivities' is available in GAD (2011c). The sensitivities are shown in Tables 6 and 7.

In order to calculate the sensitivities, GAD started by producing a central estimate of pension entitlements for the four largest schemes (civil servants, teachers, NHS, and Armed Forces) as at 31 March $2008^{35}$ on a supplementary table basis. This central estimate - $£ 636$ billion - was based

35 The March 2008 date was chosen because in order to calculate a central estimate of liabilities on the basis of the assumptions used in the supplementary table for the purposes of sensitivity analysis, GAD wished to apply the same 'duration applicable to liabilities' figure to active members, deferred members and pensioner members. This method could not be relied upon to produce robust results when Data15 (the difference between nominal discount rate for 
on the assumptions in Table 5. The absolute increases and decreases shown in Tables 6 and 7 (in $£$ billion) relate to this central estimate. However, the percentage changes on either side of the central estimate could be applied to more recent estimates (GAD 2011c, paragraph 9).

Table 6: Sensitivity analysis for financial assumptions

\begin{tabular}{|c|c|c|c|c|c|c|c|c|c|c|}
\hline Nominal discount rate (\%) & & 4.00 & 4.25 & 4.50 & 4.75 & 5.00 & 5.25 & 5.50 & 5.75 & 6.00 \\
\hline Change in pension entitlements ( $£$ billion) & & 105 & 77 & 50 & 25 & 0 & -24 & -46 & -68 & -89 \\
\hline Change in pension entitlements (\%) & & 16 & 12 & 8 & 4 & 0 & -4 & -7 & -11 & -14 \\
\hline Nominal wage increases (\%) & 3.00 & 3.25 & 3.50 & 3.75 & 4.00 & 4.25 & 4.50 & 4.75 & 5.00 & 5.25 \\
\hline Change in pension entitlements ( $£$ billion) & -35 & -28 & -21 & -14 & -7 & 0 & 7 & 15 & 23 & 31 \\
\hline Change in pension entitlements (\%) & -5 & -4 & -3 & -2 & -1 & 0 & 1 & 2 & 4 & 5 \\
\hline Rate of pension indexation (\%) & 1.50 & 1.75 & 2.00 & 2.25 & 2.50 & 2.75 & 3.00 & 3.25 & 3.50 & 3.75 \\
\hline Change in pension entitlements ( $£$ billion) & -80 & -65 & -49 & -33 & -17 & 0 & 17 & 35 & 54 & 73 \\
\hline Change in pension entitlements (\%) & -13 & -10 & -8 & -5 & -3 & 0 & 3 & 6 & 8 & 11 \\
\hline
\end{tabular}

Source: Government Actuary's Department

Table 6 shows that the estimate of pension liabilities/entitlements is most sensitive to changes in the discount rate (which is also the most variable financial assumption). A one per cent fall in the discount rate increases liabilities by 16 per cent, while a one per cent increase in the discount rate reduces liabilities by 14 per cent. GAD (2011c, paragraph 14) explains why the effect of a change in the discount rate is not symmetric.

Changes in the rate of pensions indexation also have a large impact on estimates of pension liabilities/entitlements. The supplementary table on pensions for 2010 will show the impact of the change from the RPI to the CPI for indexation of public sector employee and state pensions announced in the June 2010 budget. Changes in the rate of pensions indexation have a greater impact than changes in nominal wage increases for Column $\mathrm{G}$ schemes because changes in the rate of pensions indexation affect pensioners, deferred pensions and active members (when they retire) while changes in nominal wage growth only affect the value of pension entitlements of active members (GAD 2011c).

Table 7: Sensitivity analysis for demographic assumptions

\begin{tabular}{lcccc}
\hline & $\begin{array}{c}\text { Changes in the assumption for } \\
\text { current mortality rates }{ }^{1}\end{array}$ & $\begin{array}{c}\text { Changes in the assumptions for } \\
\text { future improvements in mortality } \\
\text { rates }^{2}\end{array}$ \\
\hline Scenario & $\begin{array}{c}\text { Lower life } \\
\text { expectancy }\end{array}$ & $\begin{array}{c}\text { Higher life } \\
\text { expectancy }\end{array}$ & $\begin{array}{c}\text { Lower life } \\
\text { expectancy }\end{array}$ & $\begin{array}{c}\text { Higher life } \\
\text { expectancy }\end{array}$ \\
\hline $\begin{array}{l}\text { Change in assumed life expectancy at age } 60 \text { for } \\
\text { current pensioners }\end{array}$ & -1.0 years & +1.0 years & -1.2 years & +1.4 years \\
$\begin{array}{l}\text { Change in assumed life expectancy at age } 60 \text { for } \\
\text { current employees }\end{array}$ & -1.0 years & +1.0 years & -2.8 years & +3.5 years \\
$\begin{array}{l}\text { Change in pension entitlements }{ }^{3}(£ \text { billion) } \\
\text { Change in pension entitlements }{ }^{3}(\%)\end{array}$ & -14 & +14 & -27 & +30 \\
\hline
\end{tabular}

1 With no change to the assumed future improvements in mortality rates (future improvements in mortality rates are based on the principal life expectancy scenario of the ONS 2008-based National Population Projections).

2 With no change to the assumed current mortality rates. Lower and higher life expectancy refers to the 'low' and 'high' life expectancy scenarios of the ONS 2008-based National Population Projections.

3 Combined effect for current pensioners and current employees.

Source: Government Actuary's Department

supplementary table and assumed rate of increase in pensions) was very different from the real discount rate. The most recent set of accounts for which the two figures were close was that dated 31 March 2008. 
Table 7 shows that the estimate of pension liabilities/entitlements is also sensitive to changes in demographic assumptions, particularly those involving changes in the assumptions about future mortality rates. The analysis presented here is based on the 'low' and 'high' life expectancy scenarios of the ONS 2008-based National Population Projections. ONS publishes new National Population Projections every two years, leading to a revised set of demographic assumptions for the resource accounts for unfunded public service pension schemes.

\section{Conclusion and forward planning}

The work being carried out by ONS to meet the requirements of ESA2010 for a supplementary table on pensions in the UK National Accounts has begun to produce results. Total pension scheme liabilities (gross) are being calculated for the first time for both funded and unfunded pensions. The table also documents flows during the year, showing how changes in total liabilities reflect amounts contributed, benefits paid out, transfers between schemes and any changes in financial or demographic assumptions.

Although the supplementary table on pensions provides a complete picture of pension provision in the UK in terms of National Accounts definitions, it excludes individual personal pensions.

However, this information will also be published by ONS. Thus, ONS will be able to provide a complete estimate of household pension entitlements in the UK (equivalent to the gross liabilities of pension providers), both on a National Accounts basis and according to broader definitions. These entitlements will include rights to state pensions as well as pensions provided through employment.

The work to compile the supplementary table on pensions is complex. Some of the challenges have been described in this article, which documents the process of compiling figures for unfunded pensions for public sector employees and of testing how sensitive the results are to changes in financial and demographic assumptions.

ONS plans to publish another article in the autumn describing the process of compiling figures for state pensions, which is being undertaken by the Department for Work and Pensions. As in the case of unfunded pensions for government employees, the work on state pensions includes sensitivity analysis to test how the results change when the underlying assumptions change, and this will be documented in the article.

Shortly the first experimental estimates for the supplementary table on pensions (for the year 2010) are produced, in December 2011, ONS will publish a third article presenting the estimates and describing how the figures in the rest of the table (the columns covering funded pensions) have been compiled. ONS expects to publish this article in early 2012 (see Table 8).

Table 8: Publication timetable for articles on the development of the National Accounts supplementary table on pensions

\begin{tabular}{|l|r|}
\hline Title of article & Publication date \\
\hline $\begin{array}{l}\text { Pensions in the National Accounts: Compiling a complete picture of UK } \\
\text { pensions including unfunded pensions for public sector employees }\end{array}$ & 3 Aug 2011 \\
\hline $\begin{array}{l}\text { Compiling estimates of state pension obligations for the National } \\
\text { Accounts (provisional title) }\end{array}$ & 25 Nov 2011 \\
\hline $\begin{array}{l}\text { The National Accounts supplementary table on pensions: experimental } \\
\text { estimates for 2010 (provisional title) }\end{array}$ & Jan/Feb 2012 \\
\hline
\end{tabular}




\section{Sources and further reading}

European Commission (2009): 2009 Ageing Report - Economic and budgetary projections for the EU-27 Member States (2008-2060), available at: http://ec.europa.eu/economy_finance/publications/publication14992_en.pdf

Eurostat/European Central Bank (2011): Technical compilation guide on pensions data in National Accounts, second draft for the Eurostat/ECB Contact Group on the statistical measurement of the assets and liabilities of pension schemes in general government. Copies available on request.

Government Actuary's Department (2011a): 'Public service pension schemes - population of the supplementary table', a methodology note dated 14 March 2011. Copies available on request.

Government Actuary's Department (2011b): 'Public service pension schemes - Duration applicable to the liabilities and the Standard Contribution Rate', 14 March 2011. Copies available on request.

Government Actuary's Department (2011c): 'Public service pension schemes - Sensitivity of measured value of pension entitlements to assumptions', 14 March 2011. Copies available on request.

HM Treasury (2003): The Green Book: Appraisal and Evaluation in Central Government. Available at: www.hm-treasury.gov.uk/data_greenbook_index.htm

HM Treasury (2009): Long-term public finance report - an analysis of fiscal sustainability, December 2009. Available at http://webarchive.nationalarchives.gov.uk/+/http://www.hmtreasury.gov.uk/prebud_pbr09_longtermfinances.htm

HM Treasury (2010): Consultation on the discount rate used to set unfunded public service pension contributions, December 2010, available at: www.hm-

treasury.gov.uk/consult_unfunded_pensions.htm

HM Treasury (2011a): Whole of Government Accounts: Unaudited Summary Report for the year ended 31 March 2010, published July 2011. Available at www.hm-

treasury.gov.uk/psr_government_accounts.htm

HM Treasury (2011b): Government Financial Reporting Manual. Available at www.hmtreasury.gov.uk/frem_index.htm).

Hobbs, D. (2009), Office for National Statistics: Wider measures of public sector debt: A broader approach to the public sector balance sheet. Available at

www.statistics.gov.uk/articles/nojournal/wider-measures-public-sector-debt.pdf

Independent Public Service Pensions Commission (IPSPC) (2010) Interim report, 7 October 2010. Available from: www.hm-treasury.gov.uk/indreview_johnhutton_pensions.htm

Independent Public Service Pensions Commission (IPSPC) (2011) Final report, 10 March 2011. Available from: www.hm-treasury.gov.uk/indreview_johnhutton_pensions.htm

Office for Budget Responsibility (2011a): Fiscal sustainability report, July 2011. Available at http://budgetresponsibility.independent.gov.uk

Office for Budget Responsibility (2011b): Economic and fiscal outlook, March 2011. Available at http://budgetresponsibility.independent.gov.uk/economic-and-fiscal-outlook-march-2011/ 
Office for National Statistics Occupational Pension Schemes Annual Report 2009, available at: www.statistics.gov.uk/StatBase/Product.asp?vlnk=1721

Office for National Statistics Pension Trends, available at www.statistics.gov.uk/pensiontrends

Müller, C., Raffelhüschen B. and O. Weddige: 'Using pension data for policy making - the case of the German pension reforms', ECB/Eurostat E-Book of the April 2009 workshop on pensions.

Available at: www.ecb.int/pub/pdf/other/ecbeurostatworkshoponpensions201002en.pdf

Pension Protection Fund/The Pensions Regulator (2010): Purple Book - DB pensions universe risk profile 2010, available at: www.pensionprotectionfund.org.uk/Pages/ThePurpleBook.aspx

Pensions Commission (2004) Pensions: Challenges and Choices, The First Report of the Pensions Commission. The Stationery Office: London.

Pensions Commission (2005) A New Pension Settlement for the Twenty-First Century, The Second Report of the Pensions Commission. The Stationery Office: London.

Rahman, S (2007): 'The treatment of pensions in the National Accounts', Economic \& Labour Market Review Vol. 1 No. 10 October 2007. Available at www.statistics.gov.uk/cci/article.asp?ID=1877\&Pos=1\&ColRank=1\&Rank=1

System of National Accounts 2008 (SNA2008), published jointly by the European Commission, the International Monetary Fund, the Organisation for Economic Co-operation and Development, the United Nations and the World Bank. New York, 2009. 


\section{Appendix 1: Adjustments to supplementary table basis}

Table A: Adjustments from resource accounts to supplementary table basis used in Table 2

\begin{tabular}{lll}
\hline Adjustment & Formula & Label \\
\hline $\begin{array}{l}\text { For liabilities at 31 March 2009 due } \\
\text { to discount rate }\end{array}$ & {$[(1+\text { Int1 }) /(1+\text { Data15a })]^{\text {Int4 }}$} & Adj1 \\
$\begin{array}{l}\text { For liabilities at 31 March 2010 due } \\
\text { to discount rate }\end{array}$ & {$\left[(1+\right.$ Int2 $) /(1+\text { Data15b) }]^{\text {Int4 }}$} & Adj2 \\
\hline
\end{tabular}

where:

\begin{tabular}{|l|l|}
\hline Int1 & Real discount rate for resource accounts at 31 March 2009 \\
\hline Int2 & Real discount rate for resource accounts at 31 March 2010 \\
\hline Data15a & $\begin{array}{l}\text { Difference between nominal discount rate for supplementary table and assumed rate } \\
\text { of increase in pensions as at 31 Mar 2009 }\end{array}$ \\
\hline Data15b & $\begin{array}{l}\text { Difference between nominal discount rate for supplementary table and assumed rate } \\
\text { of increase in pensions as at 31 Mar 2010 }\end{array}$ \\
\hline Int3 & Liabilities as at 31 March 2010 using previous year's financial assumptions \\
\hline Data 10 & Liabilities as at 31 March 2010 from resource accounts \\
\hline Int4 & $\begin{array}{l}\text { Duration applicable to liabilities, calculated as: } \\
-\ln [\text { Int3 / Data10 ] } \\
\text { ln [ }(1+\text { Int1) / (1 + Int2) ] and ln stands for natural logarithm }\end{array}$ \\
\hline
\end{tabular}

Table B: Adjustments from scheme valuation to supplementary table basis used in Table 3

\begin{tabular}{lll}
\hline Adjustment & Formula & Label \\
\hline $\begin{array}{l}\text { For liabilities at 31 March 2009 due to } \\
\text { discount rate }\end{array}$ & {$[(1+\text { Int5 }) /(1+\text { Data15 })]^{\text {Data22 }}$} & Adj3 \\
$\begin{array}{l}\text { For Standard Contribution Rate during } \\
\text { 2009/10 due to discount rate }\end{array}$ & {$[(1+\text { Int5 }) /(1+\text { Data15 })]^{\text {Data23 }}$} & Adj4 \\
\hline
\end{tabular}

where:

\begin{tabular}{|l|l|}
\hline Int5 & Real discount rate used in latest scheme valuation \\
\hline Data15 & $\begin{array}{l}\text { Difference between nominal discount rate for supplementary table and assumed } \\
\text { rate of increase in pensions }\end{array}$ \\
\hline Data22 & $\begin{array}{l}\text { Duration applicable to liabilities calculated for the latest scheme valuation (see } \\
\text { below) }\end{array}$ \\
\hline Data 23 & $\begin{array}{l}\text { Duration for the Standard Contribution Rate calculated for the latest scheme } \\
\text { valuation (see below) }\end{array}$ \\
\hline
\end{tabular}

